\title{
Corticomotor excitability in drug-naive patients with Parkinson disease
}

\section{Pobudliwość kory ruchowej u pacjentów ze świeżo rozpoznanq chorobą Parkinsona}

\author{
Mirosława Derejko, Maria Rakowicz, Jakub Antczak, Ewa Inglot, Maria Niewiadomska
}

Department of Clinical Neurophysiology, Institute of Psychiatry and Neurology, Warsaw, Poland

Neurologia i Neurochirurgia Polska 2013; 47, 2: 109-115

DOI: 10.5114/ninp.2013.34699

\begin{abstract}
Background and purpose: This study aimed to assess the indices of corticomotor excitability (CE) in drug-naive Parkinson disease $(\mathrm{PD})$ patients and to investigate its relationship with asymmetry and severity of clinical symptoms.

Material and methods: Eleven (4 men) drug-naive PD patients (mean age: $53.1 \pm 9.8$ years) and $13(7$ men) healthy controls (mean age: $51.7 \pm 4.2$ years) were included. All PD patients were rated on the motor section of the Unified Parkinson's Disease Rating Scale (UPDRS) with measurement of the side-specific score separately for arms and legs. Resting motor threshold (RMT), central silent period (CSP), amplitude of motor evoked potential (MEP) and central motor conduction time (CMCT) evoked by a single pulse of the transcranial magnetic stimulation were recorded in all subjects from the left and right abductor digiti minimi $(\mathrm{ADM})$ and extensor digitorum brevis (EDB).

Results: Parkinson disease patients showed higher MEP $(1.8 \pm 0.9$ vs. $1.1 \pm 0.8 \mathrm{mV}, p<0.05)$ and shorter CMCT $(6.1 \pm 0.9$ vs. $7.4 \pm 1.0 \mathrm{~ms}, p<0.05)$ recorded from the ADM on the more affected side. CSP recorded from the more affected $\mathrm{ADM}$ was under the normal range in five and from the less affected ADM in four PD patients. For CSP recorded from the EDB, respective values are four for the more affected side and three for the less affected side. The rigidity from the more affected arm and leg correlated negatively with the respective CSP recorded from the ADM $(r=-0.74, p<0.01)$ and $\mathrm{EDB}(r=-0.68, p<0.04)$

Conclusions: In the early stage of untreated PD the CE parameters are altered only on the more affected side. The shor-
\end{abstract}

\section{Streszczenie}

Wstęp i cel pracy: Celem badania była ocena parametrów pobudliwości korowo-ruchowej (CE) u pacjentów ze świeżo rozpoznaną chorobą Parkinsona $(\mathrm{ChP})$ oraz ich korelacji z nasileniem i asymetrią objawów klinicznych.

Materiał i metody: Badaniem objęto 11 (4 mężczyzn) pacjentów ze świeżo rozpoznaną $\mathrm{ChP}$ (średnia wieku: 53,1 \pm 9,8 roku) oraz 13 (7 mężczyzn) osób zdrowych (grupa kontrolna) (średni wiek: 51,7 $\pm 4,2$ roku). U wszystkich pacjentów dokonano oceny nasilenia objawów ruchowych według skali UPDRS z wyszczególnieniem kolejnych kończyn. U wszystkich badanych wykonano przezczaszkową stymulację magnetyczną pojedynczym impulsem z oceną: progu pobudliwości ruchowej (RMT), centralnego okresu ciszy (CSP), amplitudy wywołanego potencjału ruchowego (MEP) oraz centralnego ruchowego czasu przewodzenia (CMCT) w rejestracji z mięśni: odwodziciela palca $V(A D M)$ i prostownika krótkiego palców (EDB) obustronnie.

Wyniki: W grupie chorych na ChP stwierdzono istotnie większą amplitudę $\operatorname{MEP}(1,8 \pm 0,9$ vs $1,1 \pm 0,7 ; p<0,05)$ oraz krótszy CMCT $(6,1 \pm 0,9$ vs 7,3 $\pm 1,0 ; p<0,05)$ w rejestracji z ADM po stronie bardziej zajętej. Centralny okres ciszy dla ADM był skrócony poniżej dolnego zakresu normy ( $<64,6 \mathrm{~ms}$ ) po stronie bardziej zajętej u 5, a po stronie przeciwległej u 4 pacjentów. Skrócenie CSP dla EDB ( $<60,9$ ms) zaobserwowano odpowiednio u 4 i 3 chorych. Stwierdzono ujemną korelację pomiędzy nasileniem sztywności w kończynach z przewagą objawów a CSP dla ADM $(r=-0,74 ; p<0,008)$ i $\mathrm{EDB}(r=-0,68 ; p<0,04)$ po tej stronie.

Correspondence address: Miroslawa Derejko, Department of Clinical Neurophysiology, Institute of Psychiatry and Neurology, Sobieskiego Street 9 , 02-957 Warsaw, Poland, phone: +482245827 13,fax: +482245828 17, e-mail:mderejko@yahoo.com

Received: 26.02.2012; accepted: 17.07.2012 
tening of CSP reflects the severity of rigidity on the more affected side.

Key words: corticomotor excitability, transcranial magnetic stimulation, Parkinson disease.

\section{Introduction}

The pathophysiology of Parkinson disease (PD) includes anatomic-functional defect of the basal ganglia which affects function of motor cortical areas. The degeneration of dopaminergic nigrostriatal pathways results in functional deafferentation of the frontal cortex leading to disinhibition of the cortico-motoneuronal system and to changes in corticomotor excitability (CE). Corticomotor excitability can be investigated using transcranial magnetic stimulation (TMS). The standard CE parameters are the resting motor threshold (RMT), the motor evoked potential (MEP), the central motor conduction time (CMCT) and the central silent period (CSP). All of them are related to the functional status of the cortico-motoneuronal system $[1,2]$. The most consistent findings of TMS studies in PD are the shortening of CSP, the decrease of RMT and the increase of MEP amplitude $[3,4]$. The shortening of CMCT was also found in a few studies $[5,6]$. A number of studies, however, showed contradictory results or no changes of $\mathrm{CE}$ in $\mathrm{PD}$ patients [7-9]. One of the reasons for these discrepancies may be the influence of many clinical factors such as differences in the stage of the disease, medication and surgical treatment [2]. Furthermore, CE can differ across left and right motor cortices as the lateralisation of the symptoms is one of the early PD hallmarks.

The aim of this study was to investigate $\mathrm{CE}$ in newly diagnosed, untreated PD patients, thus avoiding the confounding effect of medication, and to assess the influence of lateralisation of clinical symptoms on $\mathrm{CE}$ in the early stage of the disease.

\section{Material and methods}

\section{Patient characteristics}

We studied 11 (4 men) right-handed, drug-naive PD patients (mean age: 53.1 years; range: $38-65$ years) and 13 age- and sex-matched healthy controls ( 7 men, mean age: 51.8 years; range $41-65$ years).

Parkinson disease was diagnosed according to the Parkinson's Disease United Kingdom Brain Bank crite-
Wnioski: We wczesnym stadium nieleczonej ChP zarejestrowano zmiany parametrów $\mathrm{CE}$ jedynie po stronie z przewagą objawów ruchowych. Skrócenie CSP korelowało z nasileniem sztywności po tej samej stronie.

Słowa kluczowe: pobudliwość kory ruchowej, przezczaszkowa stymulacja magnetyczna, choroba Parkinsona.

ria [10]. None of the participants had contraindications to TMS [11]. The PD patients were in the early disease stage (Hoehn and Yahr [H\&Y] stage $\leq 2.5$ ) with a fairly asymmetrical presentation of clinical symptoms and had never been treated with antiparkinsonian drugs or other drugs known to influence the CE parameters. The study did not include patients with tremor-dominant forms because of the well-known influence of tremor on CE parameters. In three patients, the Unified Parkinson's Disease Rating Scale (UPDRS) score was higher in the left limbs, and in 8 patients it was higher in the right limbs. Clinical details of the PD group are given in Table 1.

Each participant provided written informed consent. The study protocol was approved by the local ethics committee of the Institute of Psychiatry and Neurology in Warsaw.

\section{Study instruments}

All patients underwent a complete neurological examination. The clinical assessment also included the $\mathrm{H} \& \mathrm{Y}$ scale [12], and the UPDRS [13]. Items 22 to 26 of the UPDRS were scored for each arm and leg separately.

\section{Transcranial magnetic stimulation}

Transcranial magnetic stimulation was applied using magnetic stimulator MagStim 200 (Magstim Company Ltd, Whitland, UK). The stimulation and recording were conducted according to recommendations of the International Federation of Clinical Neurophysiology [14]. All examinations were made in the 'on' stage.

\section{Stimulation}

The 'hot spot' - the optimal stimulation site - was located by moving the coil over the primary motor cortex and delivering single TMS pulses approaching from minimal intensities to the first intensity that evoked any reliable MEP. The RMT expressed as a percentage of maximal stimulator output was defined as the minimal stimulus intensity required to produce potential of 
Table 1. Clinical characteristics of patients with Parkinson disease

\begin{tabular}{|c|c|c|c|c|c|c|}
\hline Subject & $\begin{array}{l}\text { Age (years), } \\
\text { gender }\end{array}$ & $\begin{array}{c}\text { Duration } \\
\text { of illness } \\
\text { (years) }\end{array}$ & $\begin{array}{l}\text { More affected } \\
\text { side }\end{array}$ & $\begin{array}{l}\text { Hoehn-Yahr } \\
\text { stage }\end{array}$ & $\begin{array}{l}\text { UPDRS* } \\
\text { score on more } \\
\text { affected side }\end{array}$ & $\begin{array}{l}\text { UPDRS* } \\
\text { score on less } \\
\text { affected side }\end{array}$ \\
\hline 1 & $43 \mathrm{M}$ & 0.5 & $\mathrm{~L}$ & 1 & 5 & 0 \\
\hline 2 & $64 \mathrm{~F}$ & 2 & $\mathrm{~L}$ & 2 & 9 & 3 \\
\hline 3 & $53 \mathrm{~F}$ & 2 & $\mathrm{~L}$ & 1.5 & 3 & 0 \\
\hline 4 & $57 \mathrm{~F}$ & 2 & $\mathrm{R}$ & 1 & 1 & 0 \\
\hline 5 & $65 \mathrm{~F}$ & 4 & $\mathrm{R}$ & 2.5 & 12 & 8 \\
\hline 6 & $38 \mathrm{M}$ & 2 & $\mathrm{R}$ & 1 & 5 & 0 \\
\hline 7 & $39 \mathrm{~F}$ & 2 & $\mathrm{R}$ & 2 & 10 & 2 \\
\hline 8 & $62 \mathrm{~F}$ & 3 & $\mathrm{R}$ & 3 & 11 & 6 \\
\hline 9 & $48 \mathrm{M}$ & 1 & $\mathrm{R}$ & 2 & 7 & 4 \\
\hline 10 & $56 \mathrm{M}$ & 5 & $\mathrm{R}$ & 2 & 6 & 5 \\
\hline 11 & $60 \mathrm{~F}$ & 2 & $\mathrm{R}$ & 2 & 7 & 1 \\
\hline Mean (SD) & $53.1(9.8)$ & $2.3(1.3)$ & & $1.7(0.6)$ & $6.9(3.4)$ & $2.6(2.8)$ \\
\hline
\end{tabular}

$S D$ - standard deviation, F-female, $M$ - male, L-left, $R$ - right, UPDRS - Unified Parkinson's Disease Rating Scale, *items 20-26 of the motor part (III)

amplitude of $50 \mu \mathrm{V}$ to $120 \mu \mathrm{V}$ in at least 5 of 10 stimuli delivered at an interval longer than 5 seconds to the resting abductor digiti minimi (ADM) and extensor digitorum brevis (EDB) muscles. For stimulation of motor areas of the upper extremities, a circular coil was used $(2.0$ Tesla $-530 \mathrm{~V} / \mathrm{m})$ and for motor areas of the lower extremities, the double cone coil was used (1.4 Tesla $660 \mathrm{~V} / \mathrm{m})$. For eliciting MEP, the maximal stimulator output (100\%) and for CSP stimuli of $125 \%$ intensity of RMT were applied. All stimuli except those for recording CSP were elicited during the resting state of the simulated muscles. The resting state was recognized as the isoelectric line and the silence of the loudspeakers in the continuous electromyographic (EMG) recording from the stimulated muscles.

\section{Recording}

All CE parameters (RMT, MEP, CMCT and CSP) were recorded with surface electrodes from the left and right $\mathrm{ADM}$ and $\mathrm{EDB}$. The filters of the amplifier were set at $100 \mathrm{~Hz}$ and $10 \mathrm{kHz}$.

For each extremity, the MEP was recorded at least twice to ensure the repeatability of the obtained potentials. The MEP amplitude was measured from the baseline to the first negative peak. CMCT was determined by subtracting the peripheral motor conduction time of the $\mathrm{F}$ wave from the latency of the MEP. For recording of the CSP (which is the transient cessation of the voluntary muscle activation following TMS pulse) participants were instructed to contract their ADM or EDB maximally. CSP duration was measured from the end of MEP to the evident return of voluntary EMG activity of at least $25 \%$ of pre-TMS background activity, following a period of sustained silence. For each subject, five CSP durations were averaged.

\section{Statistical analysis}

The CE parameters RMT, MEP and CMCT obtained from extremities more and less affected of the PD group were compared with the same parameters averaged from left and right extremities of the controls $[15,16]$. The CSP of the PD group was compared with the norms used in our laboratory (unpublished data) and expressed as the number of subjects having abnormal values. All CE parameters were also compared between more and less affected extremities within the PD group. Finally, all CE parameters from the more and less affected extremities were correlated with the severity of the rigidity on the respective side. The rigidity was assessed by scoring item no. 22 of the UPDRS in the upper and lower extremity and summarizing both results. The values are expressed as mean and standard deviation. The significance level was set at $p<0.05$. The Mann-Whitney $U$ test and Spearman's rank cor- 
relation coefficient were used for analysis and were done with STATISTICA (data analysis software system), version 8.0. (StatSoft, Inc., 2008).

\section{Results}

\section{Transcranial magnetic stimulation parameters in Parkinson disease patients and control group}

The mean values of CE parameters in PD patients and the control group are summarized in Table 2. The PD patients showed shorter CMCT and higher MEP recorded from the ADM of the more affected extremity. There were no significant differences in term of RMT between groups.

The CSP was shortened in five patients when recorded from the more affected ADM and in four when recorded from the contralateral ADM. The respective values for $\mathrm{EDB}$ are four and three. Two patients showed prolonged CSP recorded from the less affected ADM and one from the EDB also on the less affected side (Figs. 1 and 2). Among PD patients, the MEP record- ed from ADM of the more affected extremity was significantly higher when compared to the less affected extremity $(2.1 \pm 1.0$ vs. $1.3 \pm 0.7, p=0.01)$. There were no other intragroup differences in CE parameters.

\section{Correlation of motor symptoms with corticomotor excitability parameters}

On the more affected side, negative correlations between rigidity and CSP recorded from the ADM $(r=-0.74, p=0.008)$ and from the $\mathrm{EDB}(r=-0.68$, $p=0.039)$ were found. No correlations were found on the less affected side.

\section{Discussion}

\section{Changes in particular corticomotor excitability parameters}

This study identified the increase of the MEP amplitude and the shortening of the CMCT as the characteristic features of the early stage of PD. The increase

Table 2. Transcranial magnetic stimulation findings in PD patients and control subjects

\begin{tabular}{|c|c|c|c|}
\hline TMS parameters & Recording site & $\begin{array}{l}\text { PD patients } \\
\text { (mean } \pm \text { SD) }\end{array}$ & $\begin{array}{c}\text { Controls } \\
\text { (mean } \pm S D)\end{array}$ \\
\hline \multirow{4}{*}{$\begin{array}{l}\text { Resting motor threshold ( } \% \text { of the } \\
\text { maximal stimulator output) }\end{array}$} & ADM - more affected side & $40.5 \pm 4.5$ & \multirow[t]{2}{*}{$49.0 \pm 13.3$} \\
\hline & ADM - less affected side & $43.5 \pm 6.9$ & \\
\hline & EDB - more affected side & $41.0 \pm 5.6$ & \multirow[t]{2}{*}{$52.5 \pm 18.0$} \\
\hline & EDB - less affected side & $43.2 \pm 5.2$ & \\
\hline \multirow{4}{*}{$\begin{array}{l}\text { Amplitude of motor evoked } \\
\text { potential }[\mathrm{mV}]\end{array}$} & ADM - more affected side & $2.1 \pm 1.0^{*}$ & \multirow[t]{2}{*}{$1.1 \pm 0.7$} \\
\hline & ADM - less affected side & $1.3 \pm 0.7$ & \\
\hline & EDB - more affected side & $0.6 \pm 0.3$ & \multirow[t]{2}{*}{$0.5 \pm 0.3$} \\
\hline & EDB - less affected side & $0.6 \pm 0.5$ & \\
\hline \multirow{4}{*}{$\begin{array}{l}\text { Central motor conduction } \\
\text { time }[\mathrm{ms}]\end{array}$} & ADM - more affected side & $6.1 \pm 0.6^{* *}$ & \multirow[t]{2}{*}{$7.3 \pm 1.0$} \\
\hline & ADM - less affected side & $6.8 \pm 1.4$ & \\
\hline & EDB - more affected side & $13.1 \pm 1.7$ & \multirow[t]{2}{*}{$13.3 \pm 2.0$} \\
\hline & EDB - less affected side & $13.3 \pm 1.4$ & \\
\hline \multirow[t]{4}{*}{ Central silent period $[\mathrm{ms}]$} & ADM - more affected side & $91.2 \pm 42.3$ & \multirow{2}{*}{$\begin{array}{c}119.4 \pm 27.4 \\
\text { range: } 64.6-174.2\end{array}$} \\
\hline & ADM - less affected side & $100.3 \pm 61.2$ & \\
\hline & EDB - more affected side & $88.4 \pm 53.9$ & \multirow{2}{*}{$\begin{array}{l}135.5 \pm 37.3 \\
\text { range: } 60.9-210.2\end{array}$} \\
\hline & EDB - more affected side & $95.0 \pm 62.5$ & \\
\hline
\end{tabular}

${ }_{p} p<0.05, *{ }^{*} p<0.01$

$P D-$ Parkinson disease, TMS - transcranial magnetic stimulation, $S D$ - standard deviation

Range: mean $\pm 2 S D, A D M$ - abductor digiti minimi, $E D B$-extensor digitorum brevis 


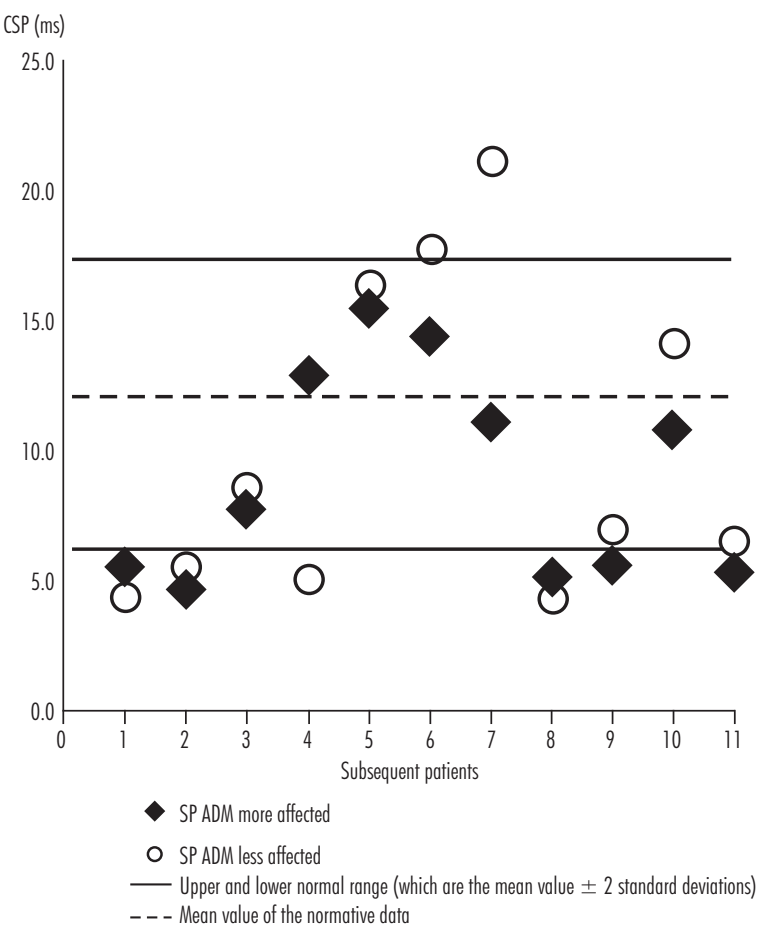

Fig. 1. Distribution of central silent period (CSP) recorded from both abductor digiti minimi muscles (ADM) in particular patients with Parkinson disease

of MEP and shortening of CMCT are associated with enhancement of the cortico-spinal excitability, which may originate from the subliminal excitation of the $\alpha$-motoneurons [17] or from the increased muscle tone [18,19]. In both circumstances, the underlying mechanism is the excessive corticospinal drive caused by disrupted control from the basal ganglia $[3,20]$. Previous studies performed mainly on medicated patients showed CMCT both shortened and normal in PD [4-6,9,17]. Similarly, the MEP amplitude was increased or normal in different medicated cohorts $[3,4,9,21]$. The MEP was also studied in untreated, early PD and was normal [22]. The recordings were however made during voluntary muscle contraction, which overshadows the influence of the excitation of $\alpha$-motoneurons [17] and of the increased muscle tone mentioned above. The changes in $\mathrm{CMCT}$ and MEP found in our untreated patients may therefore result from the alteration of $\mathrm{CE}$ caused by PD specific pathophysiology and can be seen as one of the signs of early PD.

Even though we did not find a significant difference in terms of CSP between PD patients and healthy subjects, a correlation between the severity of clinical symptoms and duration of CSP on the more affected side was present.

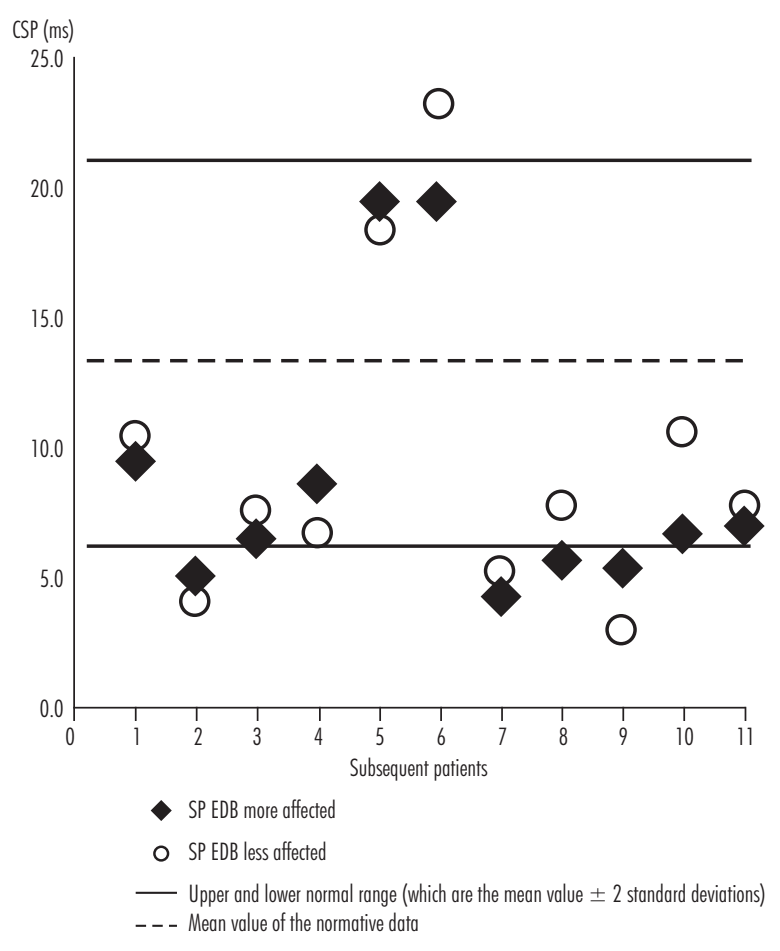

Fig. 2. Distribution of central silent period (CSP) recorded from both extensor digitorum brevis muscles (EDB) in particular patients with Parkinson disease

This reproduced the finding of Cantello et al. [22] and Berardelli et al. [23]. According to Cantello et al., the CSP differences between PD and controls are most reliably observed using near-to-maximum stimulus intensity. Stimulation of the cortex produces inhibitory phenomena within the cortico-motoneuron connection which significantly correlate with intensity of the stimulus. In the studies mentioned above and in our study, the stimuli used to achieve CSP were of intermediate strength (125-150\% of MT).

The lack of shortening of CSP in our cohort of patients could also be explained by their early stage of disease. Previous CSP studies indicating shortening of CSP have been conducted in groups of patients with a relatively advanced stage of disease $[20,24]$. According to Wu et al. [25] shorter CSP duration becomes evident as clinical symptoms advance and can reflect a compensatory response to reduced thalamo-cortical drive. Changes in cortical excitabilities as indexed by CSP durations may have greater relevance in a more advanced stage of PD associated with an evident modulation defect of dopamine and other neurotransmitters such as GABA in contrast to MEP and MT [2].

Our study did not reveal any significant differences regarding RMT between PD patients and controls. 
Resting motor threshold relates to resting membrane potential properties of cortical and spinal motor neurons [24]. Assessment of RMT in PD could be complicated by the presence of involuntary background activities which can cause a spurious lowering of MT. Our cohort of patients was in the early stage of the disease (mean H\&Y score: $1.7 \pm 0.6$ ) and had relatively mild rigidity. We were able to register quite long periods of electromyographic silence, used to measure RMT. Lowering of RMT has been widely described in PD patients since excessive drive from corticospinal fibres as an effect of disrupted control from basal ganglia is responsible for subliminal excitation of motoneurons [3]. On the other hand, prevalence of different PD signs (tremor vs. bradykinesia) may cause different and opposite changes of CE. Studies on MT in PD showed no changes [7-9], decreased MT in rigid and tremulous patients [20] or increased MT in bradykinetic patients [17]. The fact that our group was characterized by prevalence of bradykinesia and rigidity rather than tremor can explain our results. Moreover, MT usually shows remarkable inter-individual differences, also seen in our normal data.

\section{The influence of lateralisation of the clinical symptoms on corticomotor excitability}

Our results showed that in the early, drug-naive PD, $\mathrm{CE}$ changes measured with standard parameters are limited to the side with more pronounced clinical symptoms. The differences between PD and controls and the correlations with clinical symptoms were found only on this side. Also, the MEP recorded from the more affected upper limb was higher than the MEP from the opposite limb. These findings are evidence that the lateralisation of the neurodegenerative process is responsible for the asymmetry of clinical symptoms in PD. Our findings are to some extent inconsistent with Shin et al. [18], who found an increase of the MEP on the asymptomatic side, but those recordings were made during voluntary muscle effort and therefore are not comparable to ours. In addition to differences in MEP and CMCT between groups, we found a negative correlation between CSP recorded from the upper and lower extremity on the more affected side and the severity of the rigidity on this side. This finding suggests that rigidity in the early stage of $\mathrm{PD}$ corresponds to the impairment of the intracortical inhibition in the more affected hemisphere. A similar finding was made by $\mathrm{Wu}$ et al. [25] after eliciting CSP with stimuli of the maximal stimulator output.

\section{Absence of corticomotor excitability changes in the areas of the lower extremities in early Parkinson disease}

The differences in CE between groups were not present in the lower extremities. These results support those obtained by Vacherot et al. [26], who did not find any changes in RMT, MEP or CSP recorded from the anterior tibial muscle as compared to healthy subjects. According to their hypothesis, the differences in the corticospinal tract between upper and lower extremities are responsible for the lack of changes in $\mathrm{CE}$ of lower limb motor areas in early PD. The upper limb muscles are controlled mainly directly via corticomotor projections while the lumbar premotor neurons significantly influence the corticospinal transmission and thus decrease the influence of the altered CE.

The presence of a correlation between CSP recorded from the more symptomatic leg and the rigidity found in our group confirms the sensitivity of this parameter in the early stage of PD, even before the significant shortening arises. This finding may not be in line with the results of Vacherot et al. An explanation for this may be the lack of a side-specific investigation in that study [26].

\section{Study limitations}

The recent paper of Perretti et al. [27] revealed an association between PARK2 mutation and prolongation of the CMCT in PD. Since this mutation has not been investigated in our patients, we could not take this potential modifying factor into account.

\section{Conclusions}

1. The TMS examination in early, drug-naive PD patients with asymmetric presentation of clinical symptoms reveals the increase of MEP amplitude and the shortening of CMCT when recorded from the more affected upper extremity.

2. The shortening of the CSP can be a hallmark of the more advanced stage of the disease.

3. The RMT, MEP and CMCT recorded from lower extremities of PD patients in the early disease stage do not differ from controls, while CSP still reflects the severity of rigidity on the more affected side.

\section{Disclosure}

The authors report no conflict of interest. 


\section{References}

1. Mills K.R. Magnetic stimulation of the human nervous system. Oxford University Press, Oxford 1999.

2. Cantello R., Tarletti R., Civardi C. Transcranial magnetic stimulation in Parkinson's disease. Brain Res Rev 2002; 38: 309-327.

3. Cantello R., Gianelli M., Civardi C., et al. Parkinson's disease rigidity: EMG in a small hand muscle at rest. Electroencephalogr Clin Neurophysiol 1995; 97: 215-222.

4. Valls-Sole J., Pascual-Leone A., Brasil-Neto J.P., et al. Abnormal facilitation of the response to transcranial magnetic stimulation in patients with Parkinson' disease. Neurology 1994; 44: 735-741.

5. Dioszeghy P., Hidasi E., Mechler F. Study of central motor functions using magnetic stimulation in Parkinson's disease. Electromyogr Clin Neurophysiol 1999; 39: 101-105.

6. Kandler R.H., Jarrat J.A., Sagar H.J., et al. Abnormalities of central motor conduction in Parkinson's disease. J Neurol Sci 1990; 100: 94-97.

7. Tremblay F., Tremblay L.E. Cortico-motoneuron excitability of the lower limb motor representation: a comparative study in Parkinson's disease and controls. Clin Neurophysiol 2002; 113: 2006-2012.

8. Ridding M.C., Inzelberg R., Rothwell J.C., et al. Changes in excitability of motor cortical circuitry in patients with Parkinson's disease. Ann Neurol 1995; 37: 181-188.

9. Abbruzzese G., Marchese R., Trompetto C. Sensory and motor evoked potentials in multiple system atrophy: a comparative study with Parkinson's disease. Mov Disord 1997; 12: 315-321.

10. Hughes A.J., Daniel S.E., Kilford L., et al. Accuracy of clinical diagnosis of idiopathic Parkinson's disease: a clinicopathological study of 100 cases. J Neurol Neurosurg Psychiatry 1992; 51: 745-752.

11. Rossi S., Hallett M., Rossini P.M., et al.; Safety of TMS Consensus Group. Safety, ethical considerations, and application guidelines for the use of transcranial magnetic stimulation in clinical practice and research. Clin Neurophysiol 2009; 120: 20082039.

12. Hoehn M.M., Yahr M.D. Parkinsonism: onset, progression and mortality. Neurology 1967; 17: 427-442.

13. Fahn S., Elton R.L.; members of the UPDRS Development Committee. Unified Parkinson's disease rating scale. In: Fahn S., Marsden C.D., Calne D.B. [eds]. Recent developments in Parkinson's disease. Vol. 2. MacMillan Healthcare Information, Florham Park 1987; 153-156.

14. Rothwell J.C., Hallett M., Berardelli A., et al. Magnetic stimulation: motor evoked potentials. The International Federation of Clinical Neurophysiology. Electroencephalogr Clin Neurophysiol Suppl. 1999; 52: 97-103.

15. Niewiadomska M., Wochnik-Dyjas D., Głazowski C. Odcinkowe czasy przewodzenia $\mathrm{w}$ drogach ruchowych dla mięśnia odwodziciela palca $V$ ręki: metoda i wartości normatywne. Neurol Neurochir Pol 1997; 31: 1157-1166.

16. Niewiadomska M., Wochnik-Dyjas D., Głazowski C. Odcinkowe czasy przewodzenia w drogach ruchowych dla mięśnia odwodziciela krótkiego kciuka ręki: metoda i wartości normatywne. Neurol Neurochir Pol 1998; 32: 51-61.
17. Ellaway P.H., Davey N.J., Maskill D.W., et al. The relation between bradykinesia and excitability of the motor cortex assessed using transcranial magnetic stimulation in normal and parkinsonian patients. Electroencephalograph Clin Neurophysiol 1995; 97: 169-178.

18. Shin H., Kang S.Y., Lohn Y.H. Disturb surround inhibition in preclinical parkinsonism. Clin Neurophysiol 2007; 118: 21762179.

19. Day B.L., Rothwell J.C., Thompson P.D., et al. Motor cortex stimulation in intact man. II. Multiple descending volleys. Brain 1987; 110: 1191-1209.

20. Cantello R., Gianelli M., Bettucci D., et al. Parkinson's rigidity: magnetic motor evoked potentials in small hand muscle. Neurology 1991; 41: 1449-1456.

21. Nakashima K., Wang Y., Shimoda M., et al. Shortened silent period produced by magnetic cortical stimulation in patent with Parkinson's disease. J Neurosci 1995; 130: 209-214.

22. Cantello R., Tarletti R., Varrasi C., et al. Cortical inhibition in Parkinson's disease: new insights from early, untreated patients. Neuroscience 2007; 150: 64-71.

23. Berardelli A., Rona S., Inghilleri M., et al. Cortical inhibition in Parkinson's disease. A study with paired magnetic stimulation. Brain 1996; 119: 71-77.

24. Ziemman U., Lonnecker S., Steinhoff B.J., et al. Effects of antiepileptic drugs on motor cortex excitability in humans: a transcranial magnetic stimulation study. Ann Neurol 1996; 40: 367-378.

25. Wu A.D., Petzinger G.M., Lin C.J., et al. Asymmetric corticomotor excitability correlations in early Parkinson's disease. Mov Disord 2007; 22: 1587-1593.

26. Vacherot F., Attarian S., Eusebio A., et al. Excitability of the lower-limb area of the motor cortex in Parkinson's disease. Clin Neurophysiol 2010; 40: 201-208.

27. Perretti A., De Rosa A., Marcantonio L., et al. Neurophysiological evaluation of motor corticospinal pathways by TMS in idiopathic early-onset Parkinson's disease. Clin Neurophysiol 2011; 122: 546-549. 